\title{
Bacterial Bioassay for Rapid and Accurate Analysis of Arsenic in Highly Variable Groundwater Samples
}

\author{
Pham Thi Kim Trang ${ }^{1}$, Michael Berg ${ }^{2, *}$, Pham Hung Viet ${ }^{1}$, Nguyen Van Mui ${ }^{1}$, and Jan Roelof \\ van der $\mathrm{Meer}^{3} *$
}

Revised manuscript es050992e

July 20, 2005

${ }^{1}$ Research Centre for Environmental Technology and Sustainable Development (CETASD), Hanoi University of Science, 334 Nguyen Trai, Hanoi, Vietnam

${ }^{2}$ Swiss Federal Institute of Aquatic Science and Technology (Eawag), Ueberlandstraße 133, CH-8600 Dübendorf, Switzerland

${ }^{3}$ University of Lausanne, Department of Fundamental Microbiology, Bâtiment de Biologie, CH-1015 Lausanne, Switzerland

* Corresponding authors phone: +41-44-823 5078 (M.B.) or +41-21-692 5630 (J.R. vdM); fax: +41-44-823 5028 (M.B.) or +41-21-692 5605 (J.R. vdM); e-mail: michael.berg@eawag.ch (M.B.) or JanRoelof.VanDerMeer@unil.ch (J.R.vdM).

This document is the Accepted Manuscript version of a Published Work that appeared in final form in Environmental Science and Technology, copyright (C) American Chemical Society after peer review and technical editing by the publisher. To access the final edited and published work see http://doi.org/10.1021/es050992e 


\section{Abstract}

In this study we report the first ever large-scale environmental validation of a microbial reporter-based test, in order to measure arsenic concentrations in natural water resources. A bioluminescence-producing arsenic-inducible bacterium based on Escherichia coli was used as the reporter organism. Specific protocols were developed with the goal to avoid the negative influence of iron in groundwater on arsenic availability to the bioreporter cells. 194 groundwater samples were collected in the Red River and Mekong River Delta regions of Vietnam, and analyzed both by atomic absorption spectroscopy (AAS) and by the arsenic bioreporter protocol. The bacterial cells performed well at and above arsenic concentrations in groundwater of $7 \mu \mathrm{g} / \mathrm{L}$, with an almost linearly proportionally increase of the bioluminescence signal between 10 and $100 \mu \mathrm{g}$ As/L $\left(\mathrm{r}^{2}=0.997\right)$. Comparisons between AAS and arsenic bioreporter determinations gave an overall average of $8.0 \%$ false negative and $2.4 \%$ false positive identifications for the bioreporter prediction at the WHO recommended acceptable arsenic concentration of $10 \mu \mathrm{g} / \mathrm{L}$, which is far better than the performance of chemical field test kits. Because of the ease of the measurement protocol and the low application cost, the microbiological arsenic test has a great potential in large screening campaigns in Asia and other areas suffering from arsenic pollution in groundwater resources.

\section{Introduction}

Arsenic is a world-wide recurring pollutant of natural origin with serious health effects upon prolonged intake of even low concentrations. Current estimates are that, e.g., 150 million people in the West-Bengal and Bangladesh area, over 10 million in Vietnam and over 2 million in China are exposed to unacceptable arsenic intake through potable water 
consumption (1-3). Arsenicosis and visible skin lesions have been diagnosed in hundreds of thousands persons in West Bengal, Bangladesh and China $(2,4)$. A similar situation may be occurring in Vietnam, where arsenic is contaminating tube wells of around 13.5 percent of the Vietnamese population, some 11 million persons (1). Although a coarse picture on arsenic distribution in groundwater in the affected areas exists, millions of family-based groundwater tube wells remain to be measured and might potentially be safe for drinking water purposes $(2,5,6)$. Unfortunately, arsenic is spatially very heterogeneously distributed and the arsenic contents in two nearby wells within $100 \mathrm{~m}$ distance can be 30 -fold different $(1,3)$. Hence, effective arsenic mitigation campaigns should screen every individual tube well (i.e., blanket screening) to determine whether or not the quality of the potable water complies with current arsenic guideline values (for WHO: $10 \mu \mathrm{g}$ As/L, for Bangladesh currently $50 \mu \mathrm{g}$ As/L).

Considering the poor technical facilities in the most exposed countries, testing a large number of wells for arsenic contamination poses an extreme challenge. So far, mostly chemistry based commercial field test kits (e.g., Merck, Hach, Arsenator, ANN, or local imitations) have been applied in Bangladesh, India, Vietnam and other countries. The principle of these kits is the formation of volatile arsine gas $\left(\mathrm{AsH}_{3}\right)$ to separate arsenic from the aqueous matrix and subsequent colorimetric detection on a paper strip (6). Current chemical field kits have low precision, reproducibility and accuracy at arsenic concentrations between $10 \mu \mathrm{g} / \mathrm{L}$ and 100 $\mu \mathrm{g} / \mathrm{L}$. Probably, one of the most important reasons for the lack of precision is the individual variability in determining the arsenic concentration from visual inspection of colored spots (68). Results of previous field campaigns to identify the safety of potable water in tube wells have been seriously questioned because of discrepancies between results obtained with chemical test kits and independently performed laboratory measurements. For example, among 290 wells tested both by field kits and flow injection hydride generation atomic 
absorption spectroscopy (FI-HG-AAS), as much as $68 \%$ of the samples in the range of 50-100 $\mu \mathrm{g}$ As/L scored false negative in the field test and 35\% false positive (7).

Microbial reporter technologies (bacterial biosensors) have been proposed as an alternative, rapid, and cost-effective method to measure chemical species in aquatic samples. Such bioreporter microorganisms consist of genetically modified bacteria that produce a reporter protein (such as bacterial luciferase) in response to the presence of a target chemical $(9,10)$. Luminescent bacterial biosensors reacting to arsenite and arsenate have been developed as well (11-14). So far, bacterial bioreporters have mostly only been used in laboratory applications.

Arsenic-responsive bacterial bioreporters display a lower detection limit of around $4 \mu \mathrm{g}$ $\mathrm{As}(\mathrm{III}) / \mathrm{L}$ in aqueous solution with standard deviations of around $\pm 5 \%$, which is more than sufficient to comply with regulatory guidelines (11). Their precision in real groundwater samples, however, is unknown and several compounds may potentially influence the bioreporter's response, most notably ions which can complex arsenic or inhibitory substances for the bacterial cells. A few other ions may elicit a positive response from the bioreporters. Due to the nature of the exploited biological system, the arsenic bioreporters react to antimonite with a similar sensitivity as to arsenite, and to bismuth and cadmium with a 100- to 1000-fold lower sensitivity $(14,15)$. In contrast to total destructive chemical analyses, bacterial bioreporters only assess dissolved and freely diffusible arsenite and arsenate. Chemical processes, such as e.g. sorption of arsenic to precipitating iron(hydr)oxides from anoxic groundwater samples may significantly lower arsenic bioavailability to the cells, leading to underestimation of the total arsenic content of the sample $(12,16)$. 
Anoxic arsenic contaminated groundwater is often iron-rich with concentrations in the range of 5-30 mg Fe/L, with varying concentrations of other ions, such as ammonia, bicarbonate, nitrate and silicate $(1,17,18)$. During groundwater sampling procedures, acids or complexing agents are usually added to preserve the sample composition and to prevent co-precipitation of arsenic onto $\mathrm{FeOOH}$ particles, which are rapidly formed when anoxic groundwater is exposed to air (19-21).

The aim of this study was to develop a robust bioreporter protocol for rapid and reliable quantification of arsenic in natural groundwater samples exhibiting large differences in chemical composition. The presented protocol was developed in particular to eliminate potential disturbances caused by high iron concentrations in groundwater. To our knowledge this is the first time ever that bacterial bioreporters were applied on a large scale with natural field samples, and our results provide confidence in their performance and their predictive value.

\section{Experimental Section}

Groundwater Sampling. 194 groundwater samples from groundwater tube wells (family scale) were sampled in villages located in arsenic affected areas of the Red River and Mekong River deltas, Vietnam. Groundwater was collected at the tube by hand or electrical pumping. Samples were taken after 10 minutes pumping, when the oxygen concentration in the water reached a stable value, which was measured online by using a dissolved oxygen electrode (PX 3000, Mettler-Toledo). Groundwater samples $(50 \mathrm{~mL})$ were immediately filtered through 0.45 $\mu \mathrm{m}$ filters and transferred to acid-washed plastic bottles. Samples were acidified to a $\mathrm{pH}$ of 
about 2 by addition $0.1 \mathrm{~mL} \mathrm{HNO}_{3}(7.5 \mathrm{M}$, Merck) to a final concentration of $0.015 \mathrm{M}$. Water bottles were transferred to the lab, stored at $4^{\circ} \mathrm{C}$ and analyzed for arsenic within two weeks.

Arsenic Analysis by AAS and AFS. Arsenic in the groundwater samples was measured in parallel by using a HG-AAS (hydride generation AAS-6800, Shimadzu, Japan) at CETASD's laboratory, Hanoi University, Vietnam and a HG-AFS (hydride generation-atomic fluorescence spectroscopy, AFS Millenium Excalibur, PS Analytical Ltd, Kent, U.K.) at EAWAG, Switzerland. Calibration standards were prepared from a commercially available stock solution of $1000 \mathrm{mg} \mathrm{As(III)/L} \mathrm{(AAS} \mathrm{grade,} \mathrm{Fluka,} \mathrm{Switzerland)} \mathrm{and} \mathrm{de-ionized} \mathrm{water.}$ Calibration curves were established with final concentrations of $0,1,2,4,8$ and $10 \mu \mathrm{g}$ As/L $(0,0.013,0.027,0.053,0.107$ and $0.13 \mu \mathrm{M}$ respectively). The data obtained by the two methods were used to verify the Vietnamese AAS method, which was subsequently used to validate the biosensor test (see results and discussion). Standard reference materials such as the SPS-SW2 standard (Spectra pure Standard, Norway) and the ICP Multi element standard VI (Merck) were used to assure correct performance of the AAS and AFS methods.

Arsenic Analysis by Bacterial Bioreporter. The arsenic bioreporter was Escherichia coli DH5 $\alpha$ (pJAMA-arsR), which was used under the cultivation and storage conditions as described previously (11). Briefly, arsenite determination by the bacterial bioreporter is based on bioluminescence produced by the cells in response to arsenite exposure. The intensity of the bioluminescence is proportional to the arsenite concentration and can be recorded after predefined incubation periods in a luminometer. Bioreporter cells carry a plasmid with the genes for bacterial luciferase $(\operatorname{lux} A B)$ under expression control of the ArsR transcriptional repressor protein. Cellular entrance of arsenite (or antimonite) causes release of transcriptional repression and subsequent synthesis of luciferase by the cells. Arsenate is spontaneously 
reduced by the cells to arsenite and hence can also indirectly cause derepression and luciferase synthesis $(11,15)$. Bioreporter assays were conducted in $4 \mathrm{~mL}$ sterilized glass vials. The bacteria suspension was prepared just before the assay by mixing a $1.3 \mathrm{~mL}$ frozen aliquot of bacterial cells (turbidity at $600 \mathrm{~nm}$ of 0.5 ) with $10 \mathrm{~mL}$ sterilized Luria-Broth (LB) medium. Equal amounts of aqueous sample and cell suspension $(500 \mu \mathrm{L})$ were pipetted per vial, vials covered with a screw-cap and incubated on a rotary shaker at $200 \mathrm{rpm}$ and $30^{\circ} \mathrm{C}$. After 90 minutes, $50 \mu \mathrm{L}$ of $n$-decanal solution (18 $\mathrm{mM}$ in $1: 1 \mathrm{v} / \mathrm{v}$ ethanol-water) was added to the vials as substrate for the luciferase reaction. Light emission was recorded after 3 minutes in a luminometer (Junior-Berthold, Germany) and is expressed as relative light units (RLU). Each sample was measured in triplicate, from which the average light emission was calculated. The response to samples with unknown arsenic concentrations was compared to that of a standard series of arsenite concentrations, containing 0, 7.5, 15, 30, 60 and $75 \mu \mathrm{g} \mathrm{As} / \mathrm{L}(0,0.1,0.2,0.4$, 0.8 and $1 \mu \mathrm{M} \mathrm{As}$ ) and prepared in arsenic-free groundwater from the same area, but with 20 $\mathrm{mg} \mathrm{Fe} / \mathrm{L}$ of iron $(0.357 \mathrm{mM})$. Arsenic concentrations in unknown samples were determined by linear interpolation of the standard curve. In case of acidified samples, $25 \mu \mathrm{L}$ of a $200 \mathrm{mM}$ sodium pyrophosphate solution $\left(\mathrm{Na}_{4} \mathrm{P}_{2} \mathrm{O}_{7} \cdot 10 \mathrm{H}_{2} \mathrm{O}\right.$, Sigma) was added per $500 \mu \mathrm{L}$ groundwater sample to the test vial for the purpose of raising the $\mathrm{pH}$ and buffering the sample at $\mathrm{PH} \sim 7$. All analyses of groundwater samples were conducted at CETASD in Vietnam.

\section{Experiments to eliminate the Disturbance of Iron on the Response of the Bioreporters to}

Arsenic. Solutions of $\mathrm{Fe}(\mathrm{II})$ and $\mathrm{Fe}(\mathrm{III})$ were prepared in de-ionized water from $\mathrm{FeSO}_{4} \cdot 7 \mathrm{H}_{2} \mathrm{O}$ (p.a., Fluka,) and $\mathrm{FeCl}_{3} \cdot 8 \mathrm{H}_{2} \mathrm{O}$ (analytical grade, Sigma) at final concentrations in the test vials of $0,0.28,1.4,2.8,14$ and $28 \mathrm{mg} \mathrm{Fe} / \mathrm{L}(0,5,25,50,250$ and $500 \mu \mathrm{M})$. All iron-containing solutions were freshly prepared and spiked with $0.5 \mu \mathrm{M}$ As just before starting the bioreporter assay. 
In order to eliminate the negative influence of precipitating iron potentially lowering the availability of arsenic to the bacterial cells, several acids and complexing agents were evaluated for their suitability to keep iron in solution. For this purpose, aqueous solutions containing $0.325 \mu \mathrm{M}$ As and $0.1 \mathrm{mM}$ Fe(II) were prepared in test vials shortly before conducting a series of experiments. $\mathrm{HCl}, \mathrm{HNO}_{3}$ (both at $0.015 \mathrm{mM}$ final concentration), and $\mathrm{H}_{3} \mathrm{PO}_{4}(0.025 \mathrm{mM})$ were used to lower the $\mathrm{pH}$ to about 2, at which iron stays in solution. In a next step, complexing agents such as disodium ethylene-diamine-tetra-acetatedihydrate (EDTA, Fluka), tetrasodium pyrophosphate $\left(\mathrm{Na}_{4} \mathrm{P}_{2} \mathrm{O}_{7} \cdot 10 \mathrm{H}_{2} \mathrm{O}\right.$, Sigma) and trisodiumnitrilotriacetate-monohydrate (NTA, Fluka) were evaluated (all at $0.1 \mathrm{mM}$ final concentration) to sequester iron under neutral $\mathrm{pH}$ conditions, and hence, to prevent iron precipitation and subsequent adsorption of arsenic. The effect of EDTA on the response of the bioreporter in solution with $0.4 \mu \mathrm{M}$ As and $0.2 \mathrm{mM}$ Fe(II) was tested with EDTA concentrations in the range of 0 to $0.6 \mathrm{mM}$. All experiments were carried out in triplicates.

\section{Results and Discussion}

Effect of Iron on the Light Emission Induced by Arsenic from the E. coli DH5 $\alpha$ (pJAMA-arsR) Bioreporter. The effect of iron on the bioreporter response to arsenite was tested for iron concentrations in the range of $0-28 \mathrm{mg} \mathrm{Fe} / \mathrm{L}(0-0.5 \mathrm{mM}) \mathrm{Fe}(\mathrm{II})$ or $\mathrm{Fe}(\mathrm{III})$. The light emission from E. coli DH5 $\alpha$ (pJAMA-arsR) cells decreased dramatically when the iron concentration in the assay increased from $0-2.8 \mathrm{mg} \mathrm{Fe} / \mathrm{L}(0.05 \mathrm{mM})$, and no arseniteinducible light response was measurable at iron concentrations above $0.05 \mathrm{mM}$ (Figure 1a). Already $5 \mu \mathrm{M} \mathrm{Fe}(\mathrm{III})$ was sufficient to diminish the response from the bioreporter cells to 0.5 
$\mu \mathrm{M}$ arsenite. Since iron itself is not toxic for the bacterial cells, this suggests that the availability of arsenite for the cells diminished in the presence of colloidal iron hydroxides by adsorption. Fe-oxyhydroxides (any mixture of iron oxides and iron hydroxydes) are formed rapidly in aqueous solution at neutral $\mathrm{pH}$ and oxic conditions, and can adsorb $80-90 \%$ of soluble arsenite or arsenate within minutes $(22,23)$. Therefore, we concluded that the bacterial cells are not capable of sensing arsenic adsorbed to colloidal iron-hydroxide particles. We envisioned that complexing reagents or acidification of the sample to a $\mathrm{pH}$ lower than 2.5 could prevent iron oxyhydroxide formation and retain the level of luciferase induction expected from the same arsenite concentration in iron-free media. 

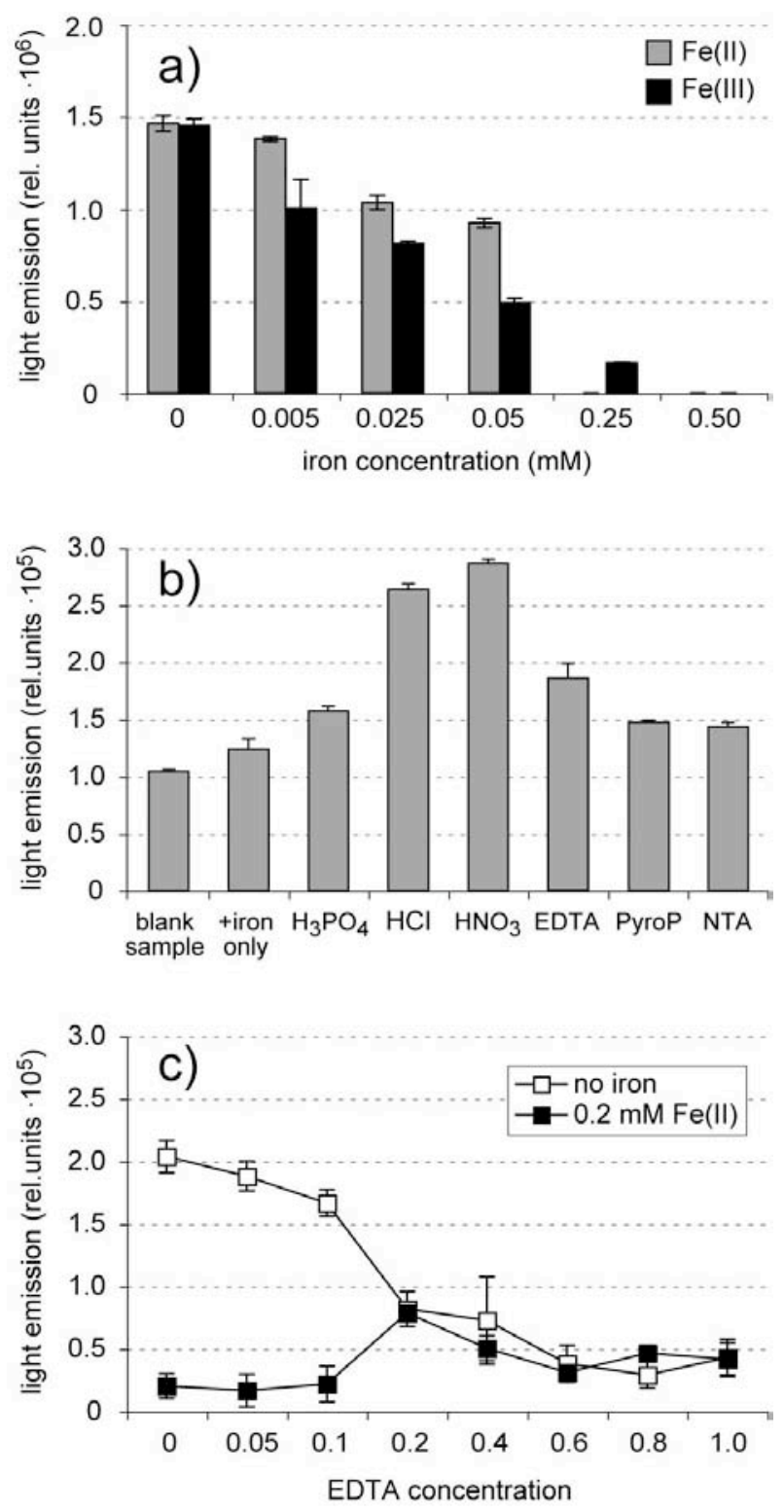

FIGURE 1. Effects of iron and iron-hydroxide solubilizing agents on the bioreporter response. a) Light emission from the bacterial cells after 90 minutes incubation with $0.5 \mu \mathrm{M}$ arsenite and different iron concentrations, as indicated. b) Light emission from the bioreporter cells with $0.3 \mu \mathrm{M}$ arsenite and $0.1 \mathrm{mM} F e(\mathrm{II})$ in the absence or presence of $0.015 \mathrm{mM} \mathrm{HCl}$ or $\mathrm{HNO}_{3}, 0.025 \mathrm{mM} \mathrm{H}_{3} \mathrm{PO}_{4}, 0.1 \mathrm{mM}$ EDTA, tetrasodium pyrophosphate or NTA. Blank sample: no iron, arsenite, or agents added. c) Effect of EDTA at different concentrations on the light emission induced by $0.4 \mu \mathrm{M}$ arsenite in the presence or absence of $0.2 \mathrm{mM} \mathrm{Fe}(\mathrm{II})$.

Evaluation of Agents for Acidification and Chelation. For this purpose $\mathrm{HCl}, \mathrm{HNO}_{3}$, and $\mathrm{H}_{3} \mathrm{PO}_{4}$ at $\mathrm{pH} 2$ or complexing agents were evaluated (see Figure 1b). In all cases an aqueous solution containing freshly prepared $0.3 \mu \mathrm{M}$ As and $0.1 \mathrm{mM} \mathrm{Fe}(\mathrm{II})$ was used as basis. The acids $\mathrm{HCl}$ and $\mathrm{HNO}_{3}$ (both at $0.015 \mathrm{mM}$ final concentration) and $\mathrm{H}_{3} \mathrm{PO}_{4}(0.025 \mathrm{mM})$ were 
added to lower the $\mathrm{pH}$ to about 2 and keep iron in solution. When the sample was subsequently mixed in a 1:1 v/v ratio with the suspended bioreporter cells, the $\mathrm{pH}$ of the assay mixture rose to 5.5. The bacterial cells were active under acidified conditions ( $\mathrm{pH} 5.5$ ), resulting in a partially restored arsenic-inducible response in the presence of iron (Figure 1b), with $\mathrm{HNO}_{3}$-acidified samples producing the highest light intensity.

Direct application of complexing agents, such as EDTA, pyrophosphate and NTA, all at 0.1 $\mathrm{mM}$ final concentration without $\mathrm{pH}$ adjustment resulted in a lower response than for $\mathrm{HCl}$ and $\mathrm{HNO}_{3}$ (Figure 1b). We tested whether the effect of EDTA could be optimized by using different EDTA concentrations in a range between 0 and $0.6 \mathrm{mM}$ (Figure 1c) on the arsenicinducible bioreporter response with $0.4 \mu \mathrm{M}$ As and $0.2 \mathrm{mM}$ Fe(II). The optimum for EDTA addition occurred at $0.2 \mathrm{mM}$ EDTA with restoration of $30 \%$ of the bioreporter response in comparison to assays without iron (Figure 1c). However, at higher EDTA concentrations, the arsenite-induced light emission decreased. Also in iron-free solutions with $0.4 \mu \mathrm{M}$ As(III), the light emission declined strongly at EDTA concentrations of $0.2 \mathrm{mM}$ and higher. EDTA therefore seems to inhibit the activity of the bacterial cells, which might be attributed to chelation of essential cations in the cell membrane (24). Although a positive influence of EDTA has been reported at both lower Fe and EDTA concentrations (25), we conclude that EDTA addition alone is not useful for bioreporter detection of arsenite in Fe-rich groundwater. 

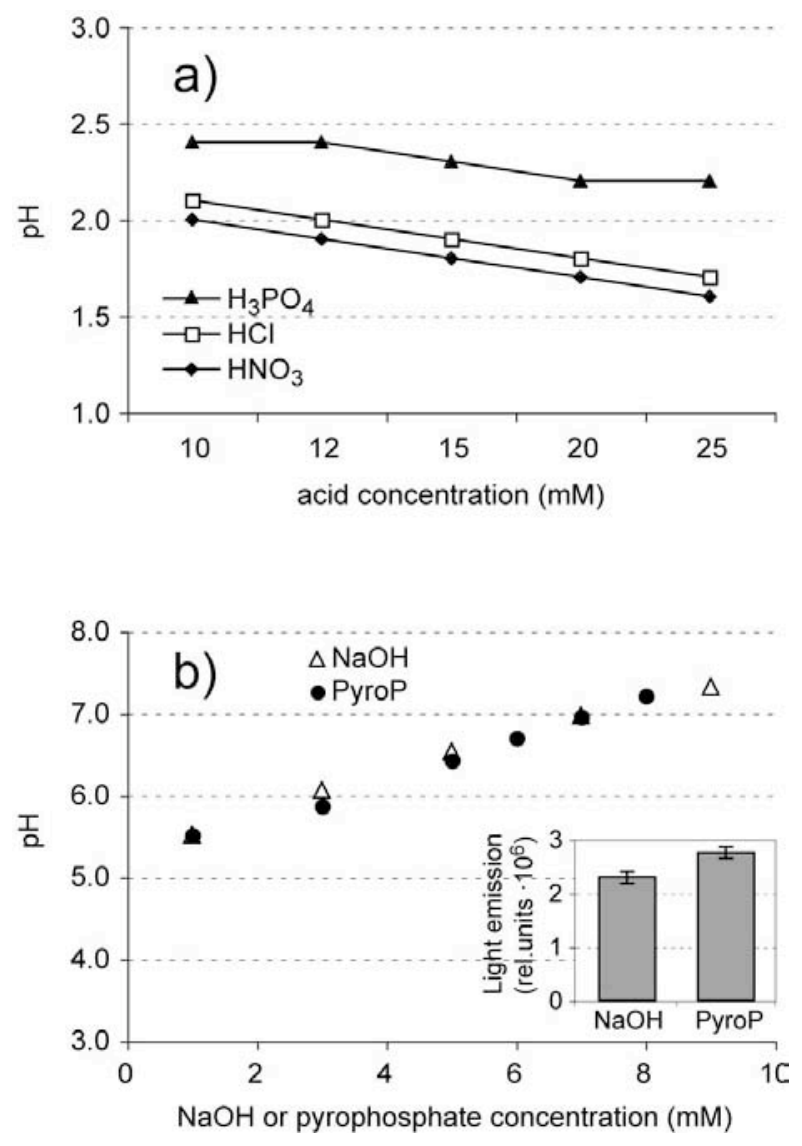

FIGURE 2. Amount of acid or base needed to acidify and thereafter neutralize groundwater samples. a) Acidification and resulting $\mathrm{pH}$ of groundwater with $\mathrm{HCl}, \mathrm{HNO}_{3}$, or $\mathrm{H}_{3} \mathrm{PO}_{4}$. b) Neutralization of $\mathrm{HNO}_{3}$ acidified $(\mathrm{pH}$ 2) groundwater samples with $\mathrm{NaOH}$ or pyrophosphate and the resulting $\mathrm{pH}$ at the indicated concentrations. Inset shows the light emission after the procedure with a groundwater containing $62 \mu \mathrm{g} / \mathrm{L}(0.83 \mu \mathrm{M})$ total arsenic at the $5 \mathrm{mM}$ concentration of neutralizing reagent.

Further optimization of the protocol was then conducted by first acidification and subsequent neutralization. Different acids such as $\mathrm{HNO}_{3}, \mathrm{HCl}$ and $\mathrm{H}_{3} \mathrm{PO}_{4}$ in concentrations between 0.01 and $0.025 \mathrm{mM}$ (all from p.a. grade, Merck) were tested to generate a $\mathrm{pH}$ of about 2 in the groundwater sample (Figure 2a). Acidified samples were then neutralized before adding the bioreporter cells by using either $200 \mathrm{mM} \mathrm{NaOH}$ or $200 \mathrm{mM} \mathrm{Na} \mathrm{P}_{2} \mathrm{O}_{7}$ aqueous solutions in final concentrations of 2, 4, 6 and $8 \mathrm{mM}$. Subsequent $\mathrm{pH}$ change and bioreporter responses in a groundwater sample with $0.83 \mu \mathrm{M}$ As were measured (Figure 2b). From this we concluded that the combination of $\mathrm{HNO}_{3}$ and $\mathrm{Na}_{4} \mathrm{P}_{2} \mathrm{O}_{7}$ at a final concentration of $5 \mathrm{mM}$ was optimal to 
dissolve any iron hydroxide complexes, neutralize the $\mathrm{pH}$ and maintain arsenite available in solution for the bioreporter cells (inset in Figure 2b).

Finally, the most successful protocol for iron-rich groundwater samples consisted of acidification to $\mathrm{pH} 1.8-2.0$ by the addition of $\mathrm{HNO}_{3}$ to a concentration of $0.015 \mathrm{mM}$, then mixing the acidified groundwater sample with LB (Luria Broth) solution containing the bacteria suspension in a 1:1 volumetric ratio, after which pyrophosphate solution (at $5 \mathrm{mM}$ final concentration) was added to readjust the $\mathrm{pH}$ to about neutral. This protocol depicted in Figure 3 was applied for all field samples.

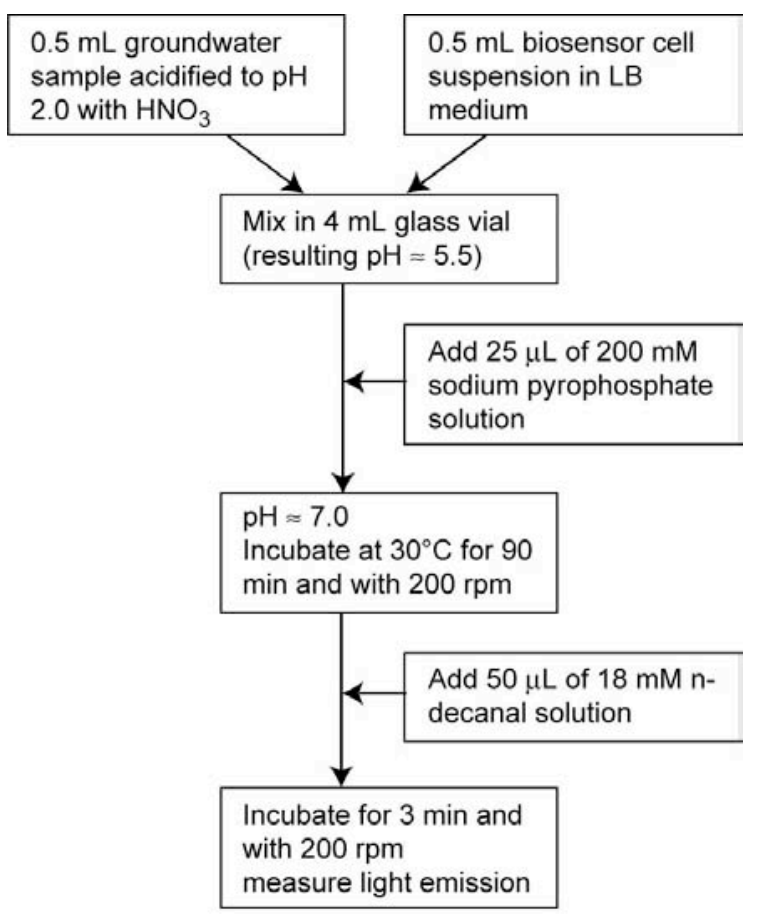

FIGURE 3. Schematic outline of the optimized procedure for arsenic bioreporter measurements in a broad variety of groundwater compositions, including iron concentrations of up to $50 \mathrm{mg} / \mathrm{L}$.

\section{Chemical Variability of Groundwater Samples and Validation of Reference Method. In}

order to establish a comparison between arsenic bioreporter and atomic absorption spectrophotometric (AAS) measurements, we first validated the AAS reference method for 
total arsenic determination at the CETASD institute in Vietnam by comparison with the AFS method performed at the EAWAG in Switzerland on a set of 111 groundwater samples collected in Vietnam. As shown in Figure 4a, the AAS and AFS measurements of total arsenic concentrations on the same sample set were perfectly in agreement $\left(r^{2}=0.992\right.$ by linear regression), hence giving confidence that the AAS applied in Vietnam would give a proper calibration for comparisons to the bioreporter-obtained values afterwards. The chemical compositions of the groundwater samples were additionally determined and were highly variable with respect to arsenic, iron, bicarbonate, phosphate, ammonium, or chloride. The concentrations of these species as well as oxygen values measured during sampling are summarized in Table 1.

TABLE 1. Chemical Composition of Groundwater Samples Analyzed in this Study

\begin{tabular}{|c|c|c|c|c|c|c|c|}
\hline \multirow{2}{*}{\multicolumn{2}{|c|}{ Chemical parameter }} & \multicolumn{3}{|c|}{ Red River Delta $(n=83)$} & \multicolumn{3}{|c|}{ Mekong River Delta $(\mathrm{n}=111)$} \\
\hline & & Min & Max & Average & Min & Max & Average \\
\hline $\mathrm{PH}$ & & 7.0 & 7.7 & 7.2 & 6.0 & 7.6 & 7.0 \\
\hline As & $(\mu \mathrm{g} / \mathrm{L})$ & 1.3 & 460 & 140 & $<1$ & 850 & 39 \\
\hline $\mathrm{Fe}$ & $(\mathrm{mg} / \mathrm{L})$ & 0.1 & 26 & 7.4 & 0.05 & 56 & 2.6 \\
\hline $\mathrm{Mn}$ & $(\mathrm{mg} / \mathrm{L})$ & $<0.01$ & 2.8 & 0.8 & $<0.01$ & 34 & 3.4 \\
\hline $\mathrm{Ca}$ & $(\mathrm{mg} / \mathrm{L})$ & 17 & 160 & 103 & 1.0 & 620 & 77 \\
\hline $\mathrm{NH}_{4}^{+}$ & $(\mathrm{mg} / \mathrm{L})$ & $<0.1$ & 24 & 8.6 & 1.5 & 25 & 7.5 \\
\hline $\mathrm{HCO}_{3}^{-}$ & $(\mathrm{mg} / \mathrm{L})$ & 310 & 730 & 582 & 96 & 900 & 318 \\
\hline $\mathrm{Cl}^{-}$ & $(\mathrm{mg} / \mathrm{L})$ & $<0.05$ & 37 & 11.6 & 2.1 & 8600 & 690 \\
\hline $\mathrm{O}_{2}$ & (mg/L) & $<0.05$ & 1.4 & 0.20 & $<0.05$ & 3.9 & 0.28 \\
\hline
\end{tabular}



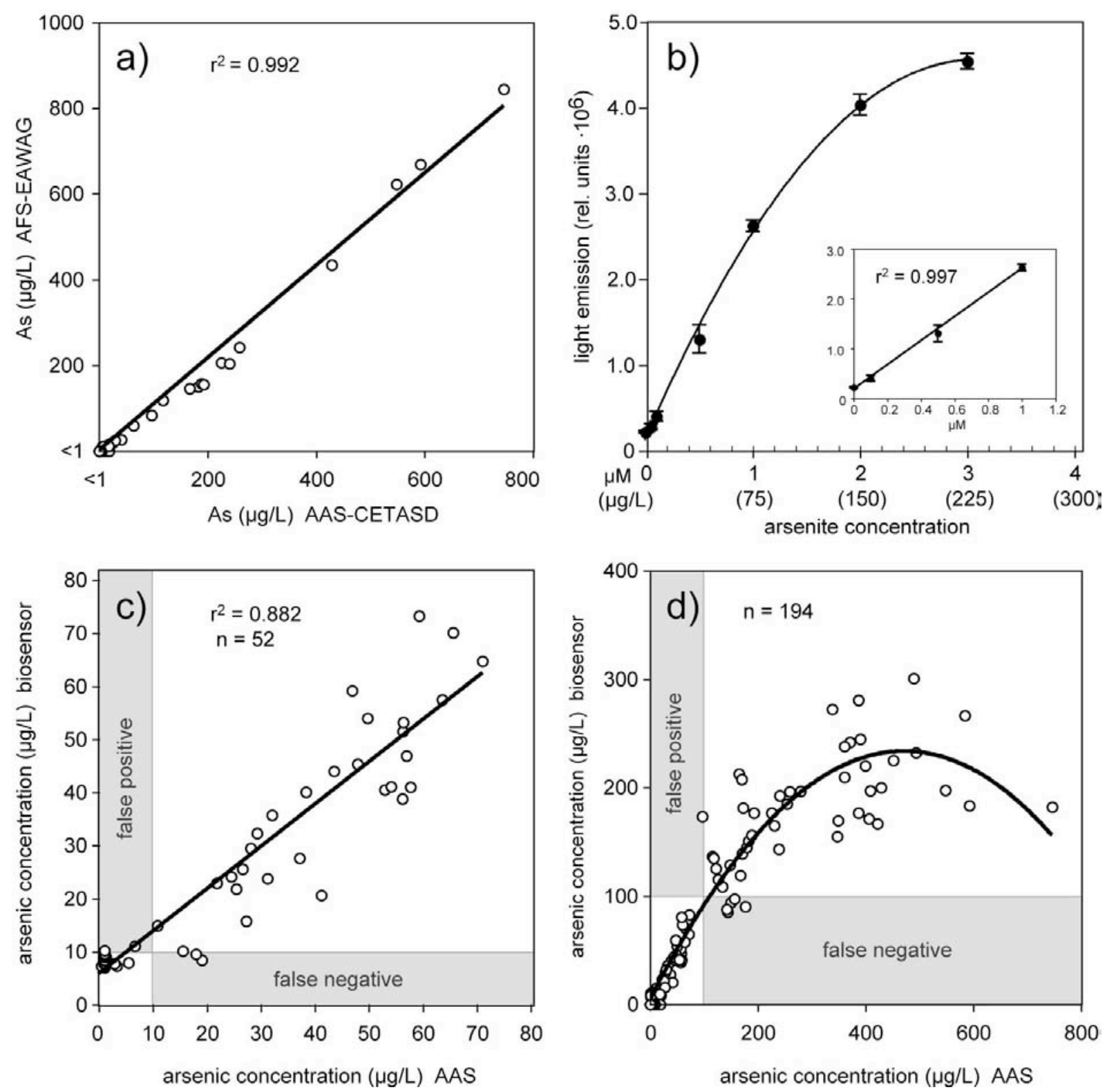

FIGURE 4. Methodological calibrations and cross-analysis of 194 groundwater samples from Vietnam by the arsenic bioreporter protocol and by atomic absorption spectroscopy (AAS). a) Comparative calibration of the AASmethod at the CETASD institute in Vietnam with the AFS-method at the EAWAG, Switzerland, on 111 groundwater samples from Vietnam, in a concentration range of between 0 and $800 \mu \mathrm{g} \mathrm{As/L.} \mathrm{b)} \mathrm{Light} \mathrm{emission}$ from the arsenic bioreporter Escherichia coli DH5 $\alpha$ (pJAMA8-arsR) as a function of arsenite concentration measured after 90 minutes incubation at $30^{\circ} \mathrm{C}$. The line represents the hyperbolic fit of the calibration. Aqueous matrix for preparing the calibration curve was arsenic-free, but iron-containing groundwater from well TD26 (20 $\mathrm{mg} \mathrm{Fe} / \mathrm{L})$. The inset shows a linear fit of the concentration range between 0 and $1 \mu \mathrm{M}$ arsenite. c) and d) Crossanalysis of 194 groundwater samples by AAS and the bioreporter protocol. Arsenic concentrations in unknown samples were interpolated from the linear $\left(0-2.8 \cdot 10^{6}\right.$ light units) or hyperbolic fits $\left(>2.8 \cdot 10^{6}\right.$ light units) of the calibration curve in panel b). Panel c) is an enlargement of the region between 7 and $70 \mu \mathrm{g} \mathrm{As} / \mathrm{L}$ of panel d). Note that a large proportion of samples was below $10 \mu \mathrm{g} \mathrm{As} / \mathrm{L}$ in both methods (Table 2) and did not contribute to the calculation of the $r^{2}$-value (linear fit) in panel c). 
Calibration Curves. Since the arsenic bioreporters' absolute light response is not only related to the arsenic concentration, but dependent on incubation time and amount of cells, the arsenic concentration in unknown samples must be inferred from a calibration curve with known arsenite concentrations analyzed simultaneously. Calibration of the bioreporter response with the new protocol (Figure 3) was therefore carried out in an arsenic-free $(<1 \mu \mathrm{g} / \mathrm{L})$ but ironcontaining $(0.18 \mathrm{mM} \mathrm{Fe}, 20 \mathrm{mg} / \mathrm{L})$ groundwater sample to which known As(III) concentrations between $0-225 \mu \mathrm{g} / \mathrm{L}(3 \mu \mathrm{M})$ were spiked. The light response of the bioreporter cells was linearly proportional to the arsenite concentration in the range between $0-75 \mu \mathrm{g} / \mathrm{L}$ $(0-1 \mu \mathrm{M})$ with $\mathrm{r}^{2}$-values equal 0.992 (Figure 4b). At higher As(III) concentrations, the bacteria response became saturated. These results were in agreement with previous calibration data in tap water (11). The detection limit in the protocol (as the value of the blank plus three times the standard deviation measured in the blank) was thus at $7.5 \mu \mathrm{g} \mathrm{As}(\mathrm{III}) / \mathrm{L}(0.1 \mu \mathrm{M})$. Consequently, the sensitivity of the bioreporter was sufficiently adequate to identify arsenite in groundwater as low as $10 \mu \mathrm{g} / \mathrm{L}$. Theoretically, a similar concentration of antimonite may elicit an equally large response from the bioreporter cells (15). Therefore, a priori, without further knowledge on the types of water, the bioreporter response may be caused by either arsenite or antimonite, or both. Antimonite concentrations in the Vietnam groundwater were mostly between 1-4 $\mu \mathrm{g} \mathrm{Sb} / \mathrm{L}$, with one exception of $13 \mu \mathrm{g} / \mathrm{L}$ (unpublished data), and, thus, have not contributed largely to the observed bioreporter responses (see below).

Rapid Screening of Field Samples with the Bacterial Bioreporter. AAS and the bioreporter assay were then used simultaneously at CETASD to measure arsenic concentrations in 194 groundwater samples collected in July 2004 from the Red River and Mekong delta regions. A comparative plot of all values generated by AAS and by the bioreporter method showed a good correlation between both methods (Figures $4 \mathrm{c}$ and d), 
especially in the low concentration range from $7-75 \mu \mathrm{g} / \mathrm{L}\left(0.1-1 \mu \mathrm{M}, \mathrm{r}^{2}=0.882\right)$. For practical reasons, water samples were used directly in the bioreporter test, leading to a twofold dilution, which is the reason for the cellular response being linear up to $150 \mu \mathrm{g} / \mathrm{L}$ (Figure $4 \mathrm{~d}$ ). If dilution factors $>2$ are applied, the accuracy of determining arsenic concentrations $>150 \mu \mathrm{g} / \mathrm{L}$ with the bioreporter cells becomes better. At the other end of the concentration scale (5-100 $\mu \mathrm{g} \mathrm{As} / \mathrm{L}$ ) the cells measured rather accurately, thus giving the bioreporter assay an important advantage over most other field kits at present.

Robustness of the Bioreporter Assay: Performance Indicators and Outlook. Assuming that the data obtained by AAS had a higher probability for being true, we calculated the percentage of false positive and false negative results obtained by the bioreporter assay for arsenic concentrations in the range of smaller than 10 , from 10-100 and higher than $100 \mu \mathrm{g}$ As/L (Table 2). The bioreporter measurement was considered false negative when the Asdetermined concentration was lower than the concentration for that category, whereas the concentration determination by AAS showed it was above. At the other way round, bioreporter measurements were considered false positive. Both of these predictions are important, because a false negative will identify a groundwater well being safe (lower than the risk category) whereas it might not be safe, with potential negative consequences for human health. False positives will identify a groundwater well as being not safe despite in fact the arsenic level is below the guideline values of $10 \mu \mathrm{g} / \mathrm{L}(7)$.

TABLE 2. Comparison of AAS with Bioreporter-Determined Arsenic Concentrations Categorized for the Vietnam Groundwater Samples $(n=194)$

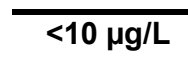

112 arsenic concentration range

$>10 \mu \mathrm{g} / \mathrm{L} \quad 10-100 \mu \mathrm{g} / \mathrm{L}$

82
38
$>100 \mu \mathrm{g} / \mathrm{L}$

44 


\begin{tabular}{lcccc} 
percentage $(\%)$ & 58 & 42 & 19 & 23 \\
number of false negatives & $9(8.0 \%)$ & - & $5(13 \%)$ & - \\
number of false positives & - & $2(2.4 \%)$ & $2(5.3 \%)$ & $1(2.3 \%)$ \\
\hline
\end{tabular}

Among the 194 tested samples, 112 samples (58\%) were determined to be safe for potable water (arsenic concentration lower than $10 \mu \mathrm{g} / \mathrm{L}$ ). For 38 samples (19\%) arsenic concentrations ranged between $10-100 \mu \mathrm{g} / \mathrm{L}$ and 44 samples (23\%) contained more than 100 $\mu \mathrm{g} / \mathrm{L}$ arsenic (see Table 2). In the range lower than $10 \mu \mathrm{g} \mathrm{As} / \mathrm{L}, 9$ samples were to be considered false negatively determined by the bioreporter $(8.0 \%)$. However, arsenic concentrations of those nine samples determined by AAS ranged between 10 to $19 \mu \mathrm{g} / \mathrm{L}$, indicating that they were not extremely off and would still be below the safety level of $50 \mu \mathrm{g}$ As/L. Among the 38 samples identified in the $10-100 \mu \mathrm{g}$ As/L range, 5 samples (13\%) were recorded as false negative by the bioreporter assay, with AAS-determined arsenic concentrations being in the range of $142-176 \mu \mathrm{g} / \mathrm{L}$, whereas two samples $(5.3 \%)$ were false positive. In 44 samples the bioreporter-determined concentration of arsenic was higher than $100 \mu \mathrm{g} / \mathrm{L}$. Among those, there were no false negative determinations, but one sample $(2.3 \%)$ was false positive with an AAS-determined value of $97 \mu \mathrm{g} / \mathrm{L}$. However, this is very close to $100 \mu \mathrm{g} / \mathrm{L}$ and can be considered as a discrepancy that can also occur between AAS tests among different laboratories (6). In summary, if all the wells were categorized as safe or not safe based on the WHO guideline value for arsenic in drinking water $(10 \mu \mathrm{g} / \mathrm{L}), 9$ of 112 samples were false negative $(8.0 \%)$ and 2 of 82 were false positive (2.4\%).

In light of the horrifying high rate of false negatives with chemical field test kits of up to $68 \%$ at arsenic concentrations in the range even of 50 to $100 \mu \mathrm{g} / \mathrm{L}(7)$, the performance of the 
bioreporter assay is very promising. Validation with a larger number of real samples from a variety of other environments as well as higher dilution ratios in the case of highly contaminated samples will improve the predictive value of the bioreporter measurements even further. But we are confident that the assays and the protocol for using the luminescent bacterial strain E. coli DH5 $\alpha$ (pJAMA-arsR) can already be an important new tool for rapid screening of arsenic in groundwater in developing countries.

It has to be emphasized that the bioassays were performed directly in Vietnam. It was the first time ever that such a microbial reporter system was tested under local conditions on a large variety of environmental samples (see Table 1). The average processing time with the single vial test was about 50 samples per day. The system can easily be upgraded to multiwell-plate analyses, allowing measurements of hundreds of samples per day, even in a moderately equipped laboratory, which is much more than can be achieved by AAS or AFS. Production of the bioreporter cells can be achieved at low costs while maintaining good quality if simple rules of handling bacteria are followed. Thus, we believe that extensive screening of many wells by this microbial reporter technology has become a more realistic opportunity to counteract the arsenic crisis.

\section{Acknowledgements}

This study was funded by the Swiss Agency for Development and Cooperation (SDC) in the framework of the Swiss-Vietnamese Cooperation Project ESTNV (Environmental Science and Technology in Northern Vietnam) and by grants to the laboratory of JRvdM. We are particularly grateful to Pham Thi Dau, Vi Mai Lan, Nguyen Thi Hue, Bui Hong Nhat (at CETASD, Vietnam) for their contributions. 


\section{Literature Cited}

(1) Berg, M.; Tran, H. C.; Nguyen, T. C.; Pham, H. V.; Schertenleib, R.; Giger, W. Arsenic contamination of groundwater and drinking water in Vietnam: A human health threat. Environ. Sci. Technol. 2001, 35, 2621-2626.

(2) Chakraborti, D.; Mukherjee, D.; Pati, S.; Sengupta, M. K.; Rahman, M.; Chowdhury, U. K.; Lodh, D.; Chanda, C. R.; Chakraborti, A. K.; Basu, G. K. Arsenic groundwater contamination in middle Ganga Plain, Bihar, India: A future danger? Environ. Health. Persp. 2003, 111, 1194-1201.

(3) Smedly, P. L.; Kinniburgh, D. G. A review of the source, behaviour and distribution of arsenic in natural waters. Appl. Geochem. 2002, 17, 517-568.

(4) Xia, Y.; Liu, J. An overview on chronic arsenism via drinking water in PR China. Toxicology 2004, 198, 25-29.

(5) Ahmed, K. M.; Bhattacharaya, P.; Hasan, M. A.; Akhter, H. S.; Alam, S. M. M.; Bhuyian, M. A. H.; Imam, M. B.; Khan, A. A.; Sracek, O. Arsenic enrichment in groundwater of the alluvial aquifers in Bangladesh: an overview. Appl. Geochem. 2004, $19,181-200$.

(6) Kinniburgh, D. G.; Kosmus, W. Arsenic contamination in groundwater: some analytical considerations. Talanta 2002, 58, 165-180.

(7) Rahman, M.; Mukherjee, D.; Sengupta, M. K.; Chowdhury, U. K.; Lodh, D.; Chanda, C. R.; Roy, S.; Selim, M.; Quamrussaman, Q.; Milton, A. H.; Shahidullah, S. M.; Rahman, M. T.; Chakraborti, D. Effectiveness and reliability of arsenic field testing kits: are the million dollar screening projects effective or not? Environ. Sci. Technol. 2002, 36, 53855394.

(8) Erickson, B. E. Field kits fail to provide accurate measure of arsenic in groundwater. Environ. Sci. Technol. 2003, 35A-38A.

(9) Daunert, S.; Barrett, G.; Feliciano, J. S.; Shetty, R. S.; Shrestha, S.; Smith-Spencer, W. Genetically engineered whole-cell sensing systems: coupling biological recognition with reporter genes. Chem. Rev. 2000, 100, 2705-2738.

(10) van der Meer, J. R.; Tropel, D.; Jaspers, M. C. M. Illuminating the detection chain of bacterial bioreporters. Environ. Microbiol. 2004, 6, 1005-1020.

(11) Stocker, J.; Balluch, D.; Gsell, M.; Harms, H.; Feliciano, J. S.; Daunert, S.; Malik, K. A.; van der Meer, J. R. Development of a set of simple bacterial biosensors for quantitative and rapid field measurements of arsenite and arsenate in potable water. Environ. Sci. Technol. 2003, 37, 4743-4750.

(12) Tauriainen, S. M.; Virta, M.; Karp, M. Detecting bioavailable toxic metal and metalloids from natural water samples using luminescent sensor bacteria. Water Res. 2000, 34, 2661-2666. 
(13) Petänen, T.; Virta, M.; Karp, M.; Romantschuk, M. Construction and use of broad host range mercury and arsenite sensor plasmids in the soil bacterium Pseudomonas fluorescens OS8. Microb. Ecol. 2001, 41, 360-368.

(14) Tauriainen, S.; Virta, M.; Chang, W.; Karp, M. Measurement of firefly luciferase reporter gene activity from cells and lysates using Escherichia coli arsenite and mercury sensors. Anal. Biochem. 1999, 272, 191-198.

(15) Scott, D. L.; Ramanathan, S.; Shi, W.; Rosen, B. P.; Daunert, S. Genetically engineered bacteria: electrochemical sensing systems for antimonite and arsenite. Anal. Chem. 1997, 69, 16-20.

(16) Petänen, T.; Romantschuk, M. Use of bioluminescent bacterial sensors as an alternative method for measuring heavy metals in soil extracts. Anal. Chim. Acta 2002, 456, 55-61.

(17) Anawar, H. M.; Akai, J.; Komari, K.; Terao, H.; Yoshioka, T.; Ishizuka, T.; Safiullah, S.; Kato, K. Geochemical occurrence of arsenic in groundwater of Bangladesh: sources and mobilization processes. J. Geochem. Explor. 2003, 77, 109-131.

(18) Duong, H. A.; Berg, M.; Hoang, M. H.; Pham, H. V.; Gallard, H.; Giger, W.; von Gunten, O. Trihalomethane formation by chlorination of ammonium- and bromidecontaining groundwater in water supplies of Hanoi, Vietnam. Water Res. 2003, 37, 3242-3252.

(19) Bednar, A. J.; Garbarino, I. R.; Ranville, J. F.; Willdeman, T. R. Preserving the distribution of inorganic arsenic species in groundwater and acid mine drainage samples. Environ. Sci. Technol. 2002, 36, 2213-2218.

(20) Daus, B.; Mattusch, J.; Wennrich, R.; Weiss, H. Investigation on stability and preservation of arsenic species in iron rich water samples. Talanta 2002, 58, 57-65.

(21) Gallagher, P. A.; Schwegel, C. A.; Parks, A.; Gamble, B. M.; Wymer, L.; Creed, J. T. Preservation of $\mathrm{As}(\mathrm{III})$ and $\mathrm{As}(\mathrm{V})$ in drinking water supply samples from across the United States using EDTA and acetic aicd as a means of minimizing iron-arsenic coprecipitation. Environ. Sci. Technol. 2004, 38, 2919-2927.

(22) Meng, X.; Korfiatis, G. P.; Bang, S.; Bang, K. W. Combined effects of anions on arsenic removal by iron hydroxides. Toxicol. Lett. 2002, 133, 103-111.

(23) Luzi, S.; Berg, M.; Pham, T. K. T.; Pham, H. V.; Schertenleib, R. "Household sand filters for arsenic removal," Swiss Federal Institute for Environmental Science and Technology, 2004.

(24) Boziaris, L. S.; Adam, M. R. Effect of chelators and nisin produced in situ on inhibition and inactivation of Gram negatives. Int. J. Food Microbiol. 1999, 53, 105-113.

(25) Harms, H.; Rime, J.; Leupin, O.; Hug, S. J.; van der Meer, J. R. Influence of the groundwater composition on arsenic detection by bacterial biosensors. Microchim. Acta in press. 